\title{
Pengaruh Corporate Governance terhadap Environmental Disclosure dengan Environmental Performance sebagai Variabel Moderating
}

\author{
Nana Nofianti \\ Lia Uzliawati \\ Sarka \\ Universitas Sultan Ageng Tirtayasa \\ Jalan Raya Jakarta KM. 04, Kec. Serang, Banten \\ E-Mail:nnofianti@ymail.com, uzliawati@yhoo.co.id, syarkashone@yahoo.co.id
}

\begin{abstract}
The purpose of this study is to examine the effect that caused the application corporate governance (Measured by the corporate governance index of the IICG) in the exercises oversight of the conduct of the environmental disclosure (Measured by IER Index of Suhardjanto), and to determine whether environmental performance the company (Measured with PROPER) as a moderating variable can be moderate influence of application corporate governance to environmental disclosure of company PROPER participants and listed in Indonesia Stock Exchange during 2010-2013 period. The method used to collect data is the purposive sampling method. Sampling criteria in this study is the Company that participate in Program Performance Rating (PROPER) 2010-2013, which listing in Indonesia Stock Exchange (IDX). The sample consists of 27 Companies selected from the population as much data as 28 the company. The results showed that: 1) corporate governance significant positive effect on environmental disclosure, and 2) environmental performance may moderate the influence of corporate governance to environmental disclosure.
\end{abstract}

Keywords: environmental disclosure, IER Index, corporate governance, environmental performance, PROPER.

\begin{abstract}
ABSTRAK
Penelitian ini bertujuan untuk menguji pengaruh yang ditimbulkan dari penerapan corporate governance (diukur dengan indeks corporate governance dari IICG) dalam menjalankan fungsi pengawasan terhadap pelaksanan environmental disclosure (diukur dengan Indeks IER dari Suhardjanto), dan untuk mengetahui apakah environmental performance perusahaan (diukur dengan peringkat PROPER) sebagai variabel moderating dapat memoderasi pengaruh dari penerapan corporate governance terhadap environmental disclosure pada perusahaan peserta Program Penilaian Peringkat Kinerja Perusahaan (PROPER) yang terdaftar di Bursa Efek Indonesia periode 2010-2013. Metode pengumpulkan data menggunakan metode purposive sampling. Kriteria pengambilan sampel dalam penelitian ini adalah perusahaan peserta PROPER 2010-2013, yang listing di Bursa Efek Indonesia (BEI). Sampel terdiri atas 27 perusahaan yang diseleksi dari populasi data sebanyak 28 perusahaan. Hasil penelitian menunjukkan bahwa: 1) corporate governance berpengaruh positif signifikan terhadap environmental disclosure, dan 2) environmental performance dapat memoderasi pengaruh dari corporate governance terhadap environmental disclosure.
\end{abstract}

Kata Kunci: environmental disclosure, Indeks IER, corporate governance, environmental performance, PROPER. 


\section{PENDAHULUAN}

Pemberitaan oleh media beberapa tahun terakhir menunjukan bahwa Indonesia mengalami permasalahan pencemaran lingkungan hidup, terutama disebabkan oleh pembuangan Bahan Berbahaya dan Beracun (B3) secara sembarangan oleh perusahaanperusahaan industri dan kimia di Indonesia (Kompas, 28 Agustus 2013).

Permasalahan pencemaran lingkungan terutama yang banyak terjadi karena kelalaian perusahaan ini. Masih banyaknya kegiatan yang mencemari lingkungan memunculkan pertanyaan tentang apa sebenarnya tujuan dari keberadaan perusahaanperusahaan tersebut. Wahyudi dan Pawestri (2006) menyatakan dalam penelitiannya bahwa selain tujuan yang berorientasi pada keuntungan, perusahaan juga mempunyai tujuan untuk mengoptimalkan nilai perusahaan, yaitu dengan bertanggung jawab sepenuhnya bukan hanya kepada pemilik (investor) tapi lebih luas lagi kepada semua stakeholder-nya. Pernyataan ini sesuai dengan teori stakeholder yang dikemukakan oleh Ghozali dan Chariri (2007), bahwa perusahaan bukanlah entitas yang hanya beroperasi dan bertujuan untuk kepentingannya sendiri, namun harus memberikan manfaat bagi stakeholder-nya (pemegang saham, kreditor, konsumen, supplier, pemerintah, masyarakat, analis, dan pihak-pihak lainnya).

Tanggung jawab perusahaan terhadap stakeholder menyebabkan pihak stakeholder secara langsung maupun tidak langsung menekankan perusahaan untuk mengungkapkan informasi yang berkaitan dengan tanggung jawab sosial dan lingkungan yang telah dilakukan oleh perusahaan, sehingga pihak stakeholder dapat menilai sejauh mana perusahaan telah menjalankan tanggung jawab sosial dan lingkungannya di masyarakat (Pflieger et al., 2005).

Suratno et al. (2006) menyatakan bahwa Environmental disclosure merupakan salah satu proses yang digunakan oleh perusahaan untuk mengungkapkan informasi berkaitan dengan kegiatan perusahaan dan pengaruhnya terhadap kondisi sosial masyarakat dan lingkungan. Environmental disclosure pada laporan tahunan perusahaan dapat menjadi sarana bagi stakeholder untuk memantau aktivitas yang dilakukan oleh perusahaan dalam memenuhi tanggung jawab sosialnya (Brown dan Deegan, 1998).
Pelaksanaan environmental disclosure pada annual report perusahaan, telah ditegaskan oleh pemerintah pada UU No. 40 Tahun 2007 pasal 66 ayat (2) poin c yang menyatakan bahwa annual report yang dibuat oleh perusahaan sekurang-kurangnya harus memuat laporan pelaksanaan tanggung jawab sosial dan lingkungan (Suhardjanto dan Yusnita, 2011). Namun meskipun begitu pada dasarnya pelaksanaan environmental disclosure di dalam laporan tahunan masih merupakan sesuatu yang bersifat voluntary atau sukarela, sehingga ada tidaknya pengungkapan ini dalam laporan tahunan bergantung pada kebijakan masing-masing perusahaan (Ahmad dan Sulaiman, 2004). Berdasarkan hasil penelitian yang dilakukan oleh Suhardjanto (2010) data penelitiannya menunjukkan bahwa rerata perusahaan di Indonesia yang mengungkapkan informasi lingkungan hidup sebesar 5,35\%. Hal ini mengindikasikan bahwa pelaku bisnis di Indonesia berkesadaran lingkungan hidup rendah.

Diperlukan adanya pengawasan terhadap pelaksanaan environmental disclosure ini agar dapat berjalan sesuai dengan peraturan yang berlaku, menurut Lins dan Warnock (2004) secara umum mekanisme yang dapat digunakan untuk mengawasi dan mengendalikan perilaku manajemen di antaranya melalui mekanisme dari corporate governance.

Terdapat empat komponen utama yang diperlukan dalam konsep Good Corporate Governance, yaitu fairness, transparency, accountability, dan responsibility. Keempat komponen tersebut penting karena penerapan prinsip Good Corporate Governance secara konsisten terbukti dapat meningkatkan kualitas laporan keuangan dan juga dapat menjadi penghambat aktivitas rekayasa kinerja yang mengakibatkan laporan keuangan tidak menggambarkan nilai fundamental perusahaan (Kaihatu, 2006).

Penelitian oleh Suhardjanto (2010) mendukung pernyataan dari Lins dan Warnock (2004) dengan hasil menunjukan bahwa keberadaan corporate governance dapat mempengaruhi pelaksanaan environmental disclosure, karena Corporate governance merupakan mekanisme yang digunakan untuk mengurangi agency problem dengan meningkatkan pemantauan terhadap tindakan manajemen, membatasi perilaku oportunistik manajer, dan mengurangi risiko informasi yang ditanggung oleh pemegang saham dan stakeholder 
(FCGI, 2013). Pengaruh dari mekanisme corporate governance terhadap pelaksanaan environmental disclosure tidak selalu berjalan efektif, tapi dapat meningkat atau melemah seiring dengan baik atau buruknya environmental performance perusahaan (Patten, 2002).

Peryataan serupa juga disampaikan oleh hasil penelitian Rao et al. (2012) yang didukung oleh penelitian Suhardjanto dan Permatasari (2010), Cong dan Freedman (2011), Uwuigbe et al. (2011) menunjukan bahwa adanya mekanisme corporate governance pada perusahaan dapat mengawasi dan mempengaruhi kinerja manager serta mendorong perusahaan untuk mengungkapkan informasi lingkungan dalam laporan keuangannya.

Clarkson et al. (2008) menyatakan bahwa berdasarkan persfektif teori legitimasi perusahaan yang unggul dalam kinerja lingkungannya memiliki insentif untuk mengkomunikasikan informasi lingkungkan perusahaan dengan membuat pengungkapan lingkungan yang sebaik-baiknya, maka pengawasan dari corporate governance terhadap pelaksanaan environmental disclosure akan menjadi efektif karena perusahaan akan secara sukarela menerbitkan laporan mengenai kinerja sosial dan lingkungannya. Sebaliknya, ketika kinerja lingkungan perusahaan berada pada tingkat yang buruk, perusahaan akan memilih untuk tidak melakukan pengungkapan sehingga pengawasan dari corporate governance terhadap pelaksanaan environmental disclosure akan menjadi tidak efektif karena perusahaan pada dasarnya akan berusaha untuk menutup-nutupi kinerjanya yang buruk agar terhindar dari ancaman legitimasi.

Fenomena yang terjadi dan uraian teori serta didukung oleh hasil penelitian terdahulu, mendorong penulis melakukan penelitian untuk menguji pengaruh corporate governance terhadap environmental disclosure dengan environmental performance sebagai variabel moderating.

\section{METODE}

Variabel Penelitian dan Operasionalisasi Variabel

Variabel independen dalam penelitian ini adalah environmental discloure yang diukur menggunakan Indonesian Environmental Report Index (IER Index) dari Suhardjanto (2008). Variabel dependen yaitu corporate governance diukur menggunakan indeks corporate governance dari Indonesian Institue for Corporate Governance (IICG), dan untuk variabel moderating yaitu environmental performance diukur menggunakan peringkat kinerja perusahaan pada Program Penilaian Kinerja Perusahaan (PROPER).

\section{Populasi dan Sampel}

Populasi dalam penelitian ini adalah seluruh perusahaan peserta Program Penilaian Peringkat kinerja Perusahaan (PROPER) pada tahun 2010-2013 yang listing di Bursa Efek Indonesia. Pengambilan perusahaan peserta PROPER sebagai objek dalam penelitian ini sesuai dengan tujuan dari penelitian yaitu mengukur tingkat environmental performance perusahaan dalam memoderasi pengaruh dari corporate governance terhadap environmental disclosure, dan perusahaan peserta PROPER sudah mewakili perusahaan-perusahaan dari yang kinerja lingkungannya buruk sampai perusahaan dengan kinerja lingkungan yang unggul (Salinan SK MENLH No. 349), berdasarkan teknik purposive sampling diperoleh sebanyak 27 perusahaan sampel.

\section{Metode Analisis Data}

Pengujian Hipotesis 1 (H1) dalam penelitian ini menggunakan analisis regresi berganda, dan untuk Hipotesis 2 (H2) menggunakan analisis regresi berganda dengan nilai selisih mutlak, dimana moderasi diukur berdasarkan nilai absolut perbedaan antara X1 dan X2 (|X1-X2|), menurut Furcot dan Shearon (1991) interaksi seperti ini lebih disukai untuk menguji ekspektasi sebelumnya berkenaan dengan pengaruh kombinasi X1 dan X2 terhadap Y, rumus persamaan regresi untuk kedua model penelitian yaitu:

$$
\begin{aligned}
& \mathrm{EDI}_{\mathrm{it}+1}=\beta_{0}+\beta_{1} \mathrm{CG}_{\mathrm{it}}+\varepsilon \\
& \mathrm{EDI}_{\mathrm{it}+1}=\beta_{0}+\beta_{1} \mathrm{ZCG}_{\mathrm{it}}+\beta_{2} \mathrm{ZEP}_{\mathrm{it}}+\beta_{3} \mathrm{AbsX1} \mathrm{X} 2_{\mathrm{it}} \\
& +\varepsilon
\end{aligned}
$$

Keterangan:

EDI : environmental disclosure pada tahun $\mathrm{t}+1$

$\mathrm{CG}_{\mathrm{it}}$ : corporate governance pada tahun $\mathrm{t}$

$\mathrm{ZCG}_{\mathrm{it}}$ : standardized score corporate governance pada tahun $\mathrm{t}$

$\mathrm{ZEP}_{\text {it }}$ : standardized score environmental performance pada tahun $\mathrm{t}$ 


\section{HASIL}

\section{Uji Asumsi Klasik}

Uji asumsi Klasik yang dilakukan terdiri dari uji normalitas, uji auto korelasi, uji muktikolinearitas, dan uji heteroskedastistas.

Distribusi normal dalam penelitian ini dideteksi dengan analisis statistik non-parametrik KolmogorovSmirnov Z (1-Sample $K-S$ ). Caranya adalah dengan terlebih dahulu menentukan hipotesis dan kriteria pengujian yaitu:

Hipotesis $0(\mathrm{Ho})$ : yang berarti data terdistribusi secara normal yaitu jika nilai Asymp. Sig. (2-tailed) $>0,05$.

Hipotesis $1(\mathrm{H} 1)$ : yang berarti data tidak terdistribusi secara normal yaitu jika nilai Asymp. Sig. (2-tailed) $<0,05$.

Adapun hasil uji one sample Kolmogorov Smirnov Test untuk model 1 dan model 2 seperti terlihat pada Tabel 1. menunjukkan bahwa dalam kedua model tersebut berdistribusi normal.

Tabel 1. Output Hasil Uji Normalitas

\begin{tabular}{cccc}
\hline Model & K-S & Asymp. Sig. & Keterangan \\
\hline Model 1 & 1.269 & 0.080 & Berdistribusi normal \\
Model 2 & 1.199 & 0.113 & Berdistribusi normal \\
\hline
\end{tabular}

Pengujian ada tidaknya gejala multikolinearitas dilakukan dengan cara melihat nilai VIF nya. Dari Tabel 2. terlihat bahwa nilai VIF baik untuk model 1 dan model 2 lebih kecil dari 10, maka dapat disimpulkan bahwa dalam model 1 dan model 2 tidak terdapat gejala multikolinearitas.

Tabel 2. Hasil Uji Multikolinearitas

\begin{tabular}{ccccl}
\multicolumn{2}{c}{ Model } & Tolerance & VIF & \multicolumn{1}{c}{ Keterangan } \\
\hline Model 1 & CG & 1.000 & 1.000 & $\begin{array}{l}\text { Tidak terjadi } \\
\text { multikolinearitas }\end{array}$ \\
& ZCG & 0.881 & 1.136 & $\begin{array}{l}\text { Tidak terjadi } \\
\text { multikolinearitas }\end{array}$ \\
Model 2 & ZEP & 0.928 & 1.078 & $\begin{array}{l}\text { Tidak terjadi } \\
\text { multikolinearitas }\end{array}$ \\
& ABSX1_X2 & 0.928 & 1.077 & $\begin{array}{l}\text { Tidak terjadi } \\
\text { multikolinearitas }\end{array}$ \\
\hline
\end{tabular}

Pengujian gejala autokorelasi dilakukan dengan menggunakan uji Durbin Watson (DW). Tabel 3. menunjukkan nilai DW statistik untuk model 1 sebesar 1,843 dan untuk model 2 sebesar 2,083.

Tabel 3. Hasil Uji Autokorelasi

\begin{tabular}{cccc}
\hline Model & DW & dl/du & Keterangan \\
\hline Model 1 & 1.843 & $1.32 / 1.47$ & Tidak terdapat autokorelasi \\
Model 2 & 2.083 & $1.16 / 1.65$ & Tidak terdapat autokorelasi \\
\hline
\end{tabular}

Pada model 1 dengan $\mathrm{n}=27$ dan $\mathrm{k}=1$, diperoleh nilai $\mathrm{dl}=1,32$ dan nilai $\mathrm{du}=1,47$, sehingga nilai $\mathrm{DW}$ statistik sebesar 1,84 berada pada daerah antara du dan 4-du, atau daerah tidak ada gejala autokorelasi. Pada model 2 dengan $\mathrm{n}=27$ dan $\mathrm{k}=3$, diperoleh nilai $\mathrm{dl}=1,16$ dan nilai $\mathrm{du}=1,65$, sehinggan nilai $\mathrm{DW}$ statistik sebesar 2,083 berada pada daerah antara du dan 4-du, atau daerah tidak ada gejala autokorelasi.
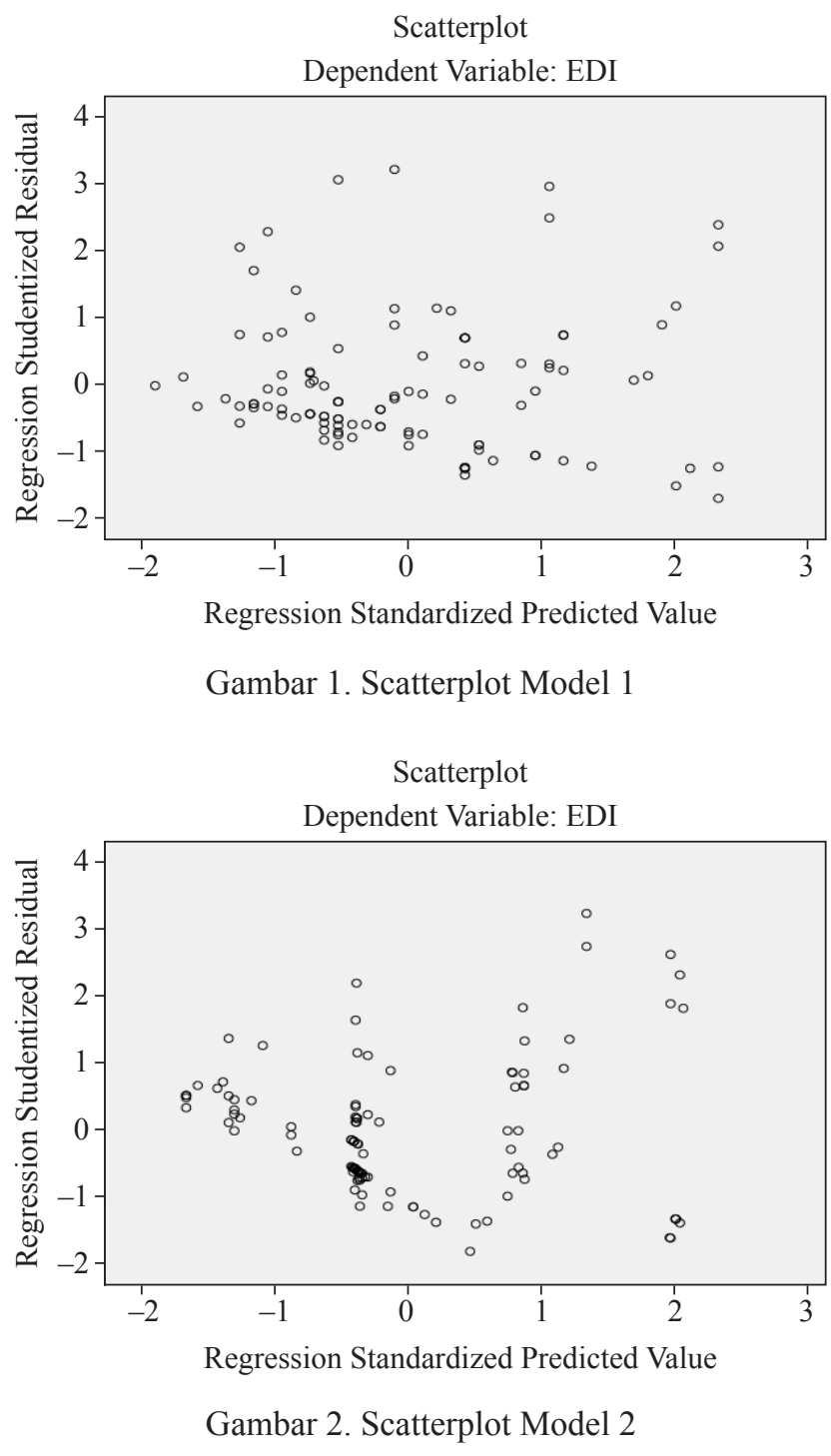
Berdasarkan grafik scatterplots model 2, terlihat bahwa titik-titik menyebar secara acak serta tersebar baik di atas maupun di bawah angka nol pada sumbu Y. Dengan demikian, dapat disimpulkan bahwa tidak terjadi heteroskedastisitas pada model 2, sehingga model 2 layak dipakai untuk memprediksi environmental disclosure berdasarkan masukan variabel corporate governance yang dimoderasi oleh environmental performance.

Analisis dengan grafik plots memiliki kelemahan yang cukup signifikan karena pada analisis ini jumlah pengamatan mempengaruhi hasil ploting. Semakin sedikit jumlah pengamatan semakin sulit menginterprestasikan hasil grafik plots. Oleh sebab itu diperlukan uji statistik yang lebih menjamin keakuratan hasil, Dalam penelitian ini, metode yang digunakan adalah Uji White. Menurut Gujarati (2003), uji ini dilihat dari nilai $\mathrm{R}^{2}$ untuk menghitung $\mathrm{c}^{2}$, di mana $\mathrm{c}^{2}=\mathrm{n} \times \mathrm{R}^{2}$. Pengujiannya adalah jika $\mathrm{c}^{2}$ hitung $<\mathrm{c}^{2}$ tabel, maka hipotesis alternatif adanya heteroskedastisitas dalam model ditolak. Adapun hasil dari uji heteroskedastisitas model 1 dan model 2 dapat dilihat pada Tabel 4.

Tabel 4. Hasil Uji White

\begin{tabular}{ccccc}
\hline Model & $\mathbf{R}^{2}$ & $\mathbf{c}^{2}$ hitung & $\mathbf{c}^{2}$ tabel & Keterangan \\
\hline Model 1 & 0.059 & 6.372 & 132.144 & $\begin{array}{c}\text { Tidak terjadi } \\
\text { heteroskedastisitas } \\
\text { Midak terjadi }\end{array}$ \\
Model 2 & 0.395 & 42.66 & 132.144 & $\begin{array}{c}\text { Tidas } \\
\text { heteroskedastisitas }\end{array}$ \\
\hline
\end{tabular}

\section{Koefisien Determinasi $\left(\mathbf{R}^{2}\right)$}

Koefisien determinasi untuk model 1 sebesar 0,118 menujukkan bahwa $11,8 \%$ perubahanperubahan yang terjadi pada variabel environmental disclosure (EDI) dapat dijelaskan oleh perubahanperubahan yang terjadi pada variabel corporate governance (CG). Pada model 2 dengan nilai $\mathrm{R}$ squared sebesar 0,630 menunjukkan bahwa sebesar $63,0 \%$ perubahan-perubahan yang terjadi pada variabel environmental disclosure (EDI) dapat dijelaskan oleh adanya perubahan-perubahan yang terjadi pada variabel standardized score corporate governance (ZCG) dan variabel standardized score environmental performance (ZEP).

Tabel 5. Koefisien Determinasi

\begin{tabular}{ccc}
\hline Model & R Square & Adjusted $R$ Square \\
\hline Model 1 & 0.118 & 0.110 \\
Model 2 & 0.630 & 0.620 \\
\hline
\end{tabular}

\section{Uji Pengaruh Simultan (F Test)}

Dari hasil regresi diperoleh nilai $\mathrm{F}$ hitung untuk model 1 sebesar 14,174 dengan probabilitas 0,000 . Karena probabilitas jauh lebih kecil dari 0,05, maka mode 1 dapat digunakan untuk memprediksi environmental disclosure di perusahaan peserta PROPER atau dapat dikatakan bahwa berdasarkan uji statistik $\mathrm{F}$, variabel corporate governance berpengaruh terhadap environmental disclosure (Ghozali, 2011).

Tabel 6. Hasil Uji Statistik F

\begin{tabular}{ccc}
\hline Model & F & Sig. \\
\hline Model 1 & 14.174 & 0.000 \\
Model 2 & 59.100 & 0.000 \\
\hline
\end{tabular}

Sumber: data sekunder yang diolah (2014)

Nilai F hitung pada model 2 sebesar 59,1 dengan probabilitas 0.000. Pobabilitas yang lebih kecil dari 0,05, maka model 2 dapat digunakan untuk memprediksi environmental disclosure di perusahaan peserta PROPER atau dapat dikatakan bahwa variabel corporate governance yang dimoderasi oleh environmental performance berdasarkan uji statistik $\mathrm{F}$ berpengaruh secara simultan terhadap environmental disclosure.

\section{Uji Parsial (Uji Statistik t)}

Tabel 7. Hasil Uji Statistik t Model 1

\begin{tabular}{cccccc}
\multicolumn{8}{c}{ Coefficients $^{\mathrm{a}}$} \\
\hline $\begin{array}{c}\text { Independent } \\
\text { Variabel }\end{array}$ & $\mathbf{B}$ & $\mathbf{t}_{\text {hitung }}$ & $\mathbf{t}_{\text {tabel }}$ & Sig. & Keterangan \\
\hline CG & 12.874 & 3.765 & 1.9826 & 0.000 & $\begin{array}{l}\text { Signifikan } \\
\text { berpengaruh } \\
\text { positif }\end{array}$ \\
\hline
\end{tabular}

Sumber: data sekunder yang diolah (2014)

Hasil uji statistikt pada Tabel 7., menunjukan bahwa variabel CG (corporate governance) memiliki arah koefisien positif. Nilai $t_{\text {hitung }}$ untuk variabel CG yang diukur menggunakan indeks corporate governance adalah sebesar 3,765 dengan tingkat signifikansi sebesar 0,000 . Oleh karena nilai $t_{\text {hitung }} 3,765>1,9826$ $\mathrm{t}_{\text {tabel }}$ dan nilai signifikansi $0,000<0,05$, maka dapat disimpulkan bahwa variabel corporate governance berpengaruh positif signifikan terhadap environmental disclosure. Hasil ini menunjukan bahwa Hipotesis 1 diterima, dan persamaan hasil regresi untuk model 1 dapat dituliskan sebagai berikut:

$\mathrm{EDI}_{\mathrm{it}+1}=7.629+12.874 \mathrm{CG}_{\mathrm{it}}$ 
Hasil pengujian menggunakan analisis regresi berganda pada model 1 , yaitu untuk menguji pengaruh dari corporate governance terhadap pelaksanaan environmental disclosure secara lengkapnya dapat dilihat pada Tabel 8 .

Tabel 8. Hasil Analisis Regresi Linier Berganda Model 1

\begin{tabular}{lcccc}
\multicolumn{5}{c}{$\mathrm{EDI}_{\mathrm{it}+1}=\beta_{0}+\beta_{1} \mathrm{CG}+\varepsilon_{\mathrm{it}}$} \\
\hline & $\begin{array}{c}\text { Predicated } \\
\text { Sign }\end{array}$ & $\begin{array}{c}\text { Model 1 } \\
\text { SQRTPBV }\end{array}$ & B & Sig \\
\hline Constant & + & 7.629 & & 0,000 \\
CG & + & 0.000 & 12.874 & $0.05^{* *}$ \\
N & & 108 & & \\
F & + & 14.174 & 0,000 \\
Sig & + & $0,05^{* *}$ & $0,05^{* *}$ \\
R & + & 0.343 & \\
R $^{2}$ & + & 0.118 & \\
Adj. $\mathrm{R}^{2}$ & + & 0.110 & \\
\hline
\end{tabular}

** Tingkat signifikansi 5\%, berdasarkan pada two-tailed test

CG - Corporate Governance

Sumber: data sekunder yang diolah (2014)

Hasil regresi model 1 menunjukkan nilai konstanta sebesar 7,629 menyatakan bahwa jika variabel independen dianggap konstan, maka ratarata environmental disclosure perusahaan adalah sebesar 7,629 \%. Koefisien regresi CG sebesar 12,874 menyatakan bahwa setiap kenaikan pengawasan dari mekanisme corporate governance perusahaan sebesar $1 \%$ akan meningkatkan pelaksanaan environmental disclosure perusahaan sebesar $12,874 \%$.

Tabel 9. Hasil Uji Statistik t Model 2

\begin{tabular}{cccccc}
\multicolumn{6}{c}{ Coefficients $^{\mathbf{a}}$} \\
$\begin{array}{c}\text { Independent } \\
\text { Variabel }\end{array}$ & $\mathrm{B}$ & $\mathbf{t}_{\text {hitung }}$ & $\mathbf{t}_{\text {tabel }}$ & Sig. & Keterangan \\
\hline $\begin{array}{c}\text { ABSX1_X2 } \\
\text { (Moderating) }\end{array}$ & 1.251 & 2.232 & 1.9826 & 0.028 & Berpengaruh \\
\hline
\end{tabular}

Sumber: data sekunder yang diolah (2014)

Hasil uji statistik t pada Tabel 9., variabel moderating (ABSX1_X2) yang dihitung dengan selisih antara CG dan EP memiliki arah koefisien positif 1,251. Nilai $t_{\text {hitung }}$ untuk variabel ABSX1_X2 adalah 2,232 dengan tingkat signifikansi sebesar 0,028 , maka variabel moderating memenuhi kriteria dengan nilai signifikan $0,028<0,05$ dan Nilai $t_{\text {hitung }}$ $2,232>1,9826 t_{\text {tabel }}$ atau dapat disimpulkan bahwa environmental performance dapat memoderasi pengaruh dari corporate governance terhadap environmental disclosure. Hasil ini menunjukkan bahwa hipotesis 1 diterima, sehingga persamaan regresi untuk model 2 dapat dituliskan sebagai berikut:

$$
\begin{aligned}
\mathrm{EDI}_{\mathrm{it}+1}= & 6.408+0.925 \mathrm{ZCG}_{\mathrm{it}}+5.057 \mathrm{ZEP}_{\mathrm{it}}+1.251 \\
& \text { ABSX1_X2 }{ }_{\mathrm{it}}
\end{aligned}
$$

Hasil pengujian menggunakan analisis regresi berganda dengan nilai selisih mutlak pada model 2, yaitu untuk menguji pengaruh dari keberadaan variabel environmental performance dalam memoderasi pengaruh dari mekanisme corporate governance dalam mengawasi pelaksanaan environmental disclosure secara lengkapnya dapat dilihat pada Tabel 10.

Tabel 10. Hasil Regresi Linier Berganda

\begin{tabular}{|c|c|c|c|c|}
\hline & $\begin{array}{l}\text { Predicated } \\
\text { Sign }\end{array}$ & $\begin{array}{c}\text { Model } 1 \\
\text { SQRTPBV }\end{array}$ & B & Sig \\
\hline Constant & + & 6.408 & & 0,000 \\
\hline ZCG & + & 0.035 & 0.925 & $0.05^{* *}$ \\
\hline ZEP & + & 0.000 & 5.057 & $0.05^{* *}$ \\
\hline $\begin{array}{l}\text { ABSX1_ } \\
X 2\end{array}$ & & 0.028 & 1.251 & $0.05^{* *}$ \\
\hline $\mathrm{N}$ & & 108 & & \\
\hline $\mathrm{F}$ & + & 14.174 & & 0,000 \\
\hline Sig & + & $0,05^{* *}$ & & $0,05^{* *}$ \\
\hline $\mathrm{R}$ & + & 0.343 & & \\
\hline $\mathrm{R}^{2}$ & + & 0.118 & & \\
\hline Adj. $R^{2}$ & + & 0.110 & & \\
\hline
\end{tabular}
dengan Nilai Selisih Mutlak Model 2

Sumber: data sekunder yang diolah (2014)

Dari hasil regresi model 2, diperoleh nilai konstanta sebesar 6,408 menyatakan bahwa jika variabel independen dianggap konstan, maka ratarata environmental disclosure perusahaan adalah sebesar, ,.408 \%. Koefisien regresi ZCG sebesar 0,925 menyatakan bahwa setiap kenaikan pengawasan dari mekanisme corporate governance perusahaan sebesar 
$1 \%$ akan meningkatkan pelaksanaan environmental disclosure perusahaan sebesar 0,925\%. Koefisien regresi ZCG sebesar 5,057 menyatakan bahwa setiap kenaikan environmental performance perusahaan sebesar $1 \%$ akan meningkatkan pelaksanaan environmental disclosure perusahaan sebesar 5,057\%. Koefisien regresi ABSX1_X2 sebesar 1,251 menyatakan bahwa setiap kenaikan environmental performance perusahaan sebesar $1 \%$ akan meningkatkan pengawasan dari mekanisme corporate governance terhadap pelaksanaan environmental disclosure perusahaan sebesar $1.251 \%$.

\section{PEMBAHASAN}

\section{Analisis Statistik Deskriptif dan Uji Asumsi Klasik}

Hasil analisis statistik deskriptif menunjukan bahwa rerata perusahaan di Indonesia yang mengungkapkan informasi lingkungan hidup hanya mencapai $22 \%$ dari skor IER yang seharusnya. Hal ini mengindikasikan bahwa pelaku bisnis di Indonesia masih memiliki tingkat kesadaran yang rendah untuk melakukan pengungkapan lingkungannya (Suhardjanto, 2010).

Hasil analisis statistik deskriptifjuga menunjukan bahwa variabel corporate governance mendapatkan performance poo. Jika disesuaikan dengan kiteria penilaian yang ditetapkan Indonesian Institute Corporate Directorship (IICD) yang menandakan bahwa rata-rata perusahaan-perusahaan dalam penelitian ini belum memenuhi nilai minimum dalam komitmen menjalankan mekanisme corporate governance menurut IICD.

Selanjutnya, berdasarkan hasil analisis statistik deskriptif menunjukan bahwa variabel environmental performance mendapatkan peringkat biru pada penilaian PROPER yang ditetapkan Kementrian Lingkungan Hidup (KLH) di mana peringkat biru diberikan kepada penanggung jawab usaha dan kegiatan yang telah melakukan upaya pengelolaan lingkungan yang dipersyaratkan sesuai dengan ketentuan atau peraturan perundang-undangan (Salinan SK MENLH No. 349).

\section{Pengaruh Corporate Governance terhadap Environmental Disclosure pada Perusahaan Peserta PROPER di Indonesia}

Hasil pengujian menunjukkan pada perusahaan PROPER yang diteliti, mekanisme corporate governance dapat menjalankan fungsi pengawasan dan pengendalian dengan baik dalam mendorong dilaksanakannya environmental disclosure yang masih bersifat voluntary disclosure atau pengungkapan sukarela.

Mekanisme Corporate governance pada perusahaan peserta PROPER juga telah mendukung berlakunya teori stakeholder yaitu untuk membatasi perilaku oportunistik manager agar bertanggung jawab bukan hanya kepada perusahaan dan investor, tetapi bertanggung jawab juga kepada semua stakeholdernya.

Tanggung jawab perusahaan terhadap para stakeholder yaitu dengan melakukan pengungkapan lingkungan untuk memberikan informasi kepada masyarakat (stakeholder) mengenai kinerja lingkungan perusahaan merupakan perwujudan dari asas transparansi. Hasil ini sejalan dengan hasil dari penelitian Rao et al. (2012), Ienciu (2012), Htay et al. (2012), Uwuigbe et al. (2011) dan Suhardjanto dan Permatasari (2010), yang menunjukan bahwa fungsi kontrol dari dewan komisaris independen yang merupakan bagian dari mekanisme corporate governance dapat mengawasi perilaku manajemen untuk meningkatkan pengungkapan lingkungan dalam laporan tahunannya.

\section{Pengaruh Environmental Performance sebagai Variabel Moderating dalam Memoderasi Pengaruh dari Corporate Governance terhadap Environmental Disclosure}

Hasil pengujian variabel moderating menggunakan model analisis regresi berganda dengan nilai selisih mutlak, menunjukkan bahwa pada perusahaan PROPER yang diteliti peringkat kinerja lingkungan dapat meningkatkan atau malah memperlemah fungsi pengawasan dan pengendalian dari mekanisme corporate governance terhadap pelaksanaan environmental disclosure perusahaan.

Hasil pengujian mendukung berlakunya teori legitimasi, yaitu teori yang menjelaskan adanya suatu kontrak sosial antara perusahaan dengan para stakeholder-nya (Ghozali dan Chariri, 2007). Menurut Deegan (2002) dalam perspektif teori legitimasi, suatu perusahaan akan secara sukarela atau menutupnutupi laporan aktifitasnya sesuai dengan baik atau buruknya tingkat environmental performance perusahaan ini berkaitan dengan adanya insentif dan disinsentif dari stakeholder, dan hal ini dapat 
memperlemah atau memperkuat fungsi pengawasan dari corporate governance. Hasil ini sejalan dengan hasil dari penelitian Clarkson et al. (2008) dan Pattern (2002). Pada penelitian lainnya menunjukkan bahwa semakin baik rangking environmental performance suatu perusahaan, maka akan berdampak baik pada kondisi organisasi perusahaan tersebut dan pada akhirnya akan semakin menstimulus pelaksanaan environmental disclosure perusahaan (Al-Tuwaijri et al., 2004).

\section{KESIMPULAN}

Berdasarkan hasil pengujian dapat disimpulkan bahwa mekanisme corporate governace berpengaruh positif signifikan terhadap pelaksanaan environmental disclosure. Hal ini menunjukan bahwa semakin baik atau tinggi pengawasan dari corporate governance, maka semakin baik juga pelaksanaan dari environmental disclosure-nya. Hasil lainnya menunjukkan bahwa environmental performance merupakan variabel yang dapat memoderasi pengaruh dari mekanisme corporate governace terhadap pelaksanaan environmental disclosure.

Saran yang bisa diberikan oleh penulis bagi praktisi adalah untuk mempertimbangkan banyaknya manfaat dilaksanakannya environmental disclosure sehingga dapat melaksanakannya sesuai dengan anjuran pemerintah melalui UU No. 40 tahun 2007, sedangkan bagi penelitian selanjutnya dapat mengembangkan penelitian ini dengan menambahkan variabel-variabel lain seperti economic performance atau kinerja keuangan, selain itu perbandingan antara perusahaan peserta PROPER dan bukan peserta PROPER dapat menjadi alternatif penelitian bagi para peneliti selanjutnya.

\section{DAFTAR PUSTAKA}

Ahmad, Nik Nazli Nik \& Sulaiman, Maliah. 2004. Environmental Disclosure in Malaysian Annual Reports: A Legitimacy Theory Perspective. International Journal of Commerce and Management, 14(1): 44-58.

Al-Tuwaijri, Sulaiman et al. 2004. The Relations Among Environmental Disclosure, Environmental Performance, and Economic Performance: A Simultaneous Equations Approach. Accounting, Organizations and Society, 29(5-6): 447-471.
Brown, Noel dan Deegan, Craig. 1998. The Public Disclosure of Environmental Performance Information - A Dual Test of Media Agenda Setting Theory and Legitimacy Theory. Accounting and Business Research, 29(1): 21-41.

Clarkson, Peter et al. 2007. Revisiting the Relation Between Environmental Performance and Environmental Disclosure: An Empirical Analysis. Accounting, Organizations and Society, 33: 303327.

Cong, Yu \& Freedman, Martin. 2011. Corporate Governance and Environmental Performance and Disclosure. Advances in Accounting, Incorporating Advances in International Accounting, 27: 223232.

Deegan, Craig. 2002. The Legitimizing Effect Of Social And Environmental Disclosures: A Theoretical Foundation. Accounting, Auditing and Accountability Journal, 15(3): 282-311.

Forum for Corporate Governance in Indonesia (FCGI). 2013. Tata kelola Perusahaan (Corporate Governance). www.cic-fcgi.org. [Online] diakses 20 Januari 2014.

Frucot, Veronique \& Shearon, Winston T. 1991. Budgetary Participation, Locus of Control and Mexican Managerial Performance and Job Satisfaction. The Accounting Review, 66(1): 8089.

Ghozali, Imam \& Chariri, Anis. 2007. Teori Akuntansi. Semarang: Badan Penerbit UNDIP.

Ghozali, Imam. 2011. Aplikasi Analisis Multivariate dengan Program SPSS. Semarang: Badan Penerbit Universitas Diponegoro

Gujarati, Damodar N. 2003. Basic Econometrics (4 ${ }^{\text {th }}$ edition). New York: McGraw-Hill.

Htay, Sheila $\mathrm{Nu} \mathrm{Nu}$ et al. 2012. Impact of Corporate Governance on Social and Environmental Information Disclosure of Malaysian Listed Banks: Panel Data Analysis. Asian Journal of Finance \& Accounting, 4(1): 1-24.

Ienciu, Ionel-Alin. 2012. The Relationship Between Enviromental Reporting and Corporate Governance Characteristics of Romanian Listed Entities. Journal of Accounting and Management Information Systems, 11(2): 267-294.

Kaihatu, Thomas S. 2006. Good Corporate Governance dan Penerapannya di Indonesia. Jurnal Manajemen dan Kewirausahaan, 8(1): $1-9$. 
Rao,KathyayiniKathyetal.2012.Corporate Governance and Environmental Reporting: An Australian Study. Corporate Governance. 12(2): 143-163.

Lins, Karl V. \& Warnock, Francis E. 2004. Corporate Governance and the Shareholder Base. International Finance Discussion Papers, (816).

Patten, Dennis M. 2002. The Market Reaction to Social Responsibility Disclosure: The Case of the Sullivan Principles Signings. Accounting Organization and Society, 15(6): 575-587.

Pflieger, Julia et al. 2005. The Contribution of Life Cycle Assessment to Global Sustainability Reporting of Organization. Management of Environmental Quality: An International Journal, 16(2): 167-179.

Suhardjanto, Djoko. 2008. Environmental Reporting Practies: An Evidence From Indonesia. Jurnal Akuntansi dan Bisnis, 8(1): 33-46.

Suhardjanto, Djoko. 2010. Corporate Governance, Karakteristik Perusahaan Dan Environmental Disclosure. Prestasi, 6(01): 39-69.

Suhardjanto, Djoko \& Permatasari, Novita Dian. 2010. Pengaruh Corporate Governance, Etnis, dan Latar Belakang Pendidikan Terhadap Environmental Disclosure. KINERJA, 14(2): 151-164.
Suhardjandto, Djoko \& Yusnita, Theodora. 2011. Pengaruh Corporate Governance terhadap Environmetal Performance di Indonesia. Akuntabilitas, 10(2): 330-347.

Suratno, Ignatius Bondan et al. 2006. Pengaruh Environmental Performance terhadap Environmental Disclousure dan Economic Performance (Studi Empiris pada Perusahaan Manufaktur yang Terdaftar di Bursa Efek Jakarta Periode (2001-2004). Simposium Nasional Akuntansi 9.

Uwuigbe, Uwalomwa et al. 2011. The Effect of Board Size and Board Composition on Firms Corporate Environmental Disclosure: A Study of Selected Firms in Nigeria. Acta Universitatis Danubius: Oeconomica, 7(5): 164-176.

Wahyudi, Untung \& Pawestri, Hartini Prasetyaning. 2006. Implikasi Struktur Kepemilikan terhadap Nilai Perusahaan: Dengan Keputusan Keuangan sebagai Variabel Intervening. Simposium Nasional Akuntansi 9.

YPPMI Sinergi Communication. 2002. The Essence of Good Corporate Governance. Jakarta: YPPMI Sinergi Communication. 